\title{
DETERMINATION OF THE EFFECT OF EDGE BANDING THICKNESS AND AGING PERIOD ON THE MOR AND MOE OF MELAMINE COATED PARTICLE BOARD USING TAGUCHI METHOD
}

\author{
Cevdet Sacli, Suleyman Neseli
}

Original scientific paper In this study, the aging period $(20,30,40$ and 50 days), the edge banding thickness $(0,4 ; 0,8 ; 1,0$ and 2,0 $\mathrm{mm})$ and the type of force used (bending strengthMOR and tensile strength-MOE) were the parameters selected for analysis of the effects on the mechanical properties of melamine coated particle board. To do this, Taguchi's methodology for the design of experiments was used to optimize the process parameters. Trials are conducted using an $L_{16}$ orthogonal array with 16 combinations of test variables to assess the influence of various factors. Analysis of variance was also employed to investigate which design parameters significantly affect the mechanical properties of melamine coated particle board. The statistical analysis showed that the type of force used was the most significant factor affecting the response. The simulated and experimental results also showed good agreement with each other.

Keywords: aging; bending and tensile strength; Taguchi method; wood composite

\section{Određivanje utjecaja debljine kantiranja i razdoblja starenja na savojnu i vlačnu čvrstoću melaminom obložene iverice uporabom Taguchi metode}

Izvorni znanstveni članak

U ovom istraživanju, razdoblje starenja (20, 30, 40 i 50 dana), debljina kantiranja (0,4; 0,8; 1 i 2 mm) i vrsta ostvarivanja sile (savojna čvrstoća - MOR i vlačna čvrstoća - MOE) odabrani su kao parametri za analizu učinaka na mehanička svojstva melaminom obložen iverice. U tu svrhu, Taguchijevo oblikovanje metodologije pokusa provedeno je za optimizaciju procesnih parametara. Pokusi su provedeni po ortogonalnom polju $L_{16}$ sa 16 kombinacija ispitnih varijabli za procjenu utjecaja različitih čimbenika. Analiza varijance također je bila uključena za istraživanje koji parametri konstrukcije značajno utječu na mehanička svojstva melaminom obložene iverice. Statistička je analiza pokazala da vrsta ostvarivanja sile krajnje promjenjivo djeluje na odziv. Simulirani i eksperimentalni rezultati također pokazuju dobro slaganje jednih s drugima.

Ključneriječi: kompozitno drvo; savojna i vlačna čvrstoća; starenje; Taguchi metoda

\section{Introduction}

Over the past several decades, industrial grade, wood based panels have been recognized throughout the furniture industry as an ideal substrate for Melamine Coated Particleboard (MCP) constructions, utilizing various types of overlay surfacing and edge banding materials.

Particle board is manufactured in the form of panels to utilize wood waste, sawdust and slab wood. It finds applications in furniture manufacturing and in flooring etc. Wood particles are pressed into sheets using some synthetic bonding adhesive. The particle board panel forms a sandwich structure [1].

During the manufacture of wooden particle boards, the particles are strongly compressed. When the panels get moist (e.g. while aqueous adhesives are applied), the thickness of the dense particles swells (spring-back effect), accompanied by an increase in surface roughness. At the same time, the mechanical strength of the moisture-absorbing structure is decreased [2].The strength and durability of wood-based composite products are a function of the mechanical properties of its component materials. It is not usually desirable to use a material that experiences rapid changes caused by moisture, because moisture affects the physical and mechanical properties of woody materials. Shrinkage is approximately proportional to the amount of water lost from the cell wall [3].

Edge banding is thought to be the most important protective factor in furniture making. Polyvinylchloride (PVC) edge banding is manufactured from high-quality resins and high-impact modifiers that produce a product with excellent machinability, impact resistance, durability and overall appearance. There are various types of edgebanding materials such as PVC, acrylic, Acrylonitrile Butadiene Styrene (ABS), melamine, solid wood or a wood veneer [4].

In cabinet manufacture, an advantage of using melamine-coated Medium Density Fiberboard (MDF) with edge banding is the higher ultimate strength of the final product. The higher strength of the structure can increase the cabinet's lifetime by showing more resistance to repeated loads [5]. In cabinets manufactured from uncoated MDF, the failure generally starts from the top panel and the failure mode is closer to the findings of Kasal et al. [6] and this frequency increased in treated cabinets.

The rate of heat transfer is important, because most adhesives require a curing temperature above $100{ }^{\circ} \mathrm{C}$ for polymerization. If the resin is not fully cured during this process, the board could debone due to expanding internal vapour pressure [7]. Ayrilmis et al. [8] showed that the thermal treatment of rubber woodfibers significantly lowered the flexural properties, internal bond strength and screw withdrawal resistance of MDF panels. The resulting internal bond strength clearly indicated that the bonding ability is affected by thermal treatment at elevated temperatures. Swelling of the panel thickness significantly improved with increasing temperature and time of treatment. Reduced swelling of the thickness of the MDF panels made from thermally-treated fibers was mainly attributed to hemicelluloses being hydrolysed during the thermal treatment. MDF panels made from thermally-treated rubber woodfibers at $180^{\circ} \mathrm{C}$ for $30 \mathrm{~min}$ 
appeared to be a practical choice for applications requiring reduced thickness swelling.

Malanit et al. [9] reported that high temperature caused increasing resin bonding and resulted in better strength. A low temperature and a short pressing time will cause pre-curing of the adhesive, while a high temperature and longer pressing time will cause adhesive over-curing. Pre- and over-curing will reduce the bonding strength of the particle board.

The thermal conductivity of the wood was measured experimentally by using a heat flow meter and a transient plane source technique for oven dry and moist specimens, respectively. The specimens included five species for both softwoods (China-fir, Korean pine, Masson pine, Scots pine and larch) and hardwoods (basswood, birch, and red, yellow and white lauan), which are widely available and used in China. Firstly, transverse thermal conductivity was calculated as a function of oven-dry density for ovendry specimens, to obtain a correlating linear equation. Secondly, the temperature dependency of transverse thermal conductivity of the oven-dry specimens was calculated up to $90^{\circ} \mathrm{C}$. An almost linearly increasing trend was observed for each of the softwood and hardwood species between $30^{\circ} \mathrm{C}$ and $80{ }^{\circ} \mathrm{C}$ [10].

It can be observed that the changes in both MOR and MOE were not significant when the temperature was increased from $25^{\circ} \mathrm{C}$ to $75^{\circ} \mathrm{C}$. The MOR and MOE decreased by $28,3 \%$ and $29,7 \%$ respectively. A monotonic and linearly decreasing relationship has been reported between the MOR with the temperature between $20^{\circ} \mathrm{C}$ to $140{ }^{\circ} \mathrm{C}$ and an exposure time of $180 \mathrm{~min}$. However, in this study both MOR and MOE did not change significantly when the temperature increased from $75^{\circ} \mathrm{C}$ to $125^{\circ} \mathrm{C}[11]$.

Engineered composites such as MCPhave been frequently used in furniture panel manufacturing, especially for middle-class end users. Natural moisture fluctuation in panel furniture during its daily life will affect its mechanical strength due to temperature variations. Precisetechnical knowledge in this area can help designers and manufacturers of panel furniture have a deeper understanding how their products react in a service location, as well as predicting their service life. None of the existing studies considerthe ambient temperature differences between day and night and its mechanical effect on MCP. Consequently, humidity changes were examined in the laboratory. The aim of this study of day and night temperature differences - which at the local level has reached about 30 to $40^{\circ} \mathrm{C}$ in Turkeyis to investigate how the mechanical resistance provided by the edge-band thickness changes in the furniture used in daily life. Thus, depending on the climatic conditions of the wood composite manufacturing areas it will be possible to provide better performing, environmentfriendly, lower-cost manufacturing

To the best of our knowledge, there have been no studies on the simultaneous investigation of various formulation and processing parameters on the mechanical characteristics of MCP. The forces developed during the use of any products composed of MCP can cause damage reducing the appearance as well as the performance. This study was performed to evaluate the effects of the edgebanding thickness and aging period on the MOR and
MOE strength of MCP using the Taguchi method to determine the optimum parameter combination. We can then see whether the control of process parameters can improve the strength of MCP.

\section{Experimental details \\ 2.1 Composite material}

Particle board is produced by mechanically reducing the raw wood material into small particles, applying adhesive to the particles, and compressing a loose mat of the particles with heat and pressure into a panel product [12]. MCP is produced in five layers according to TS-EN 312 [13]. Both of the outer faces of the board consist of thin melamine; the layer under the melamine consists of fine wood particles, with the core made from coarser material (See Fig. 1).

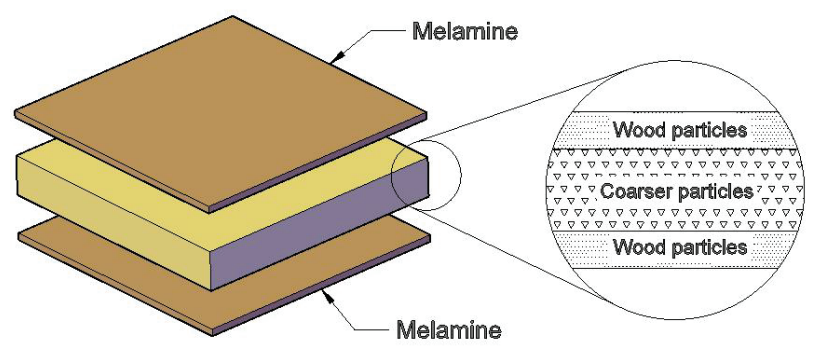

Figure 1 The layers of MCP

MS-type particle board chips used in the middle layer are obtained by the parallel intersection chip method, whereas DS-type chips are used on the outer surface. A blend of $60 \%$ wood flour is used in the production of MS sawdust. DS chip uses a $40 \%$ blend. Sixty percent hardwood sawdust beech wood chips (Fagus orientalis) and $40 \%$ (Populous tremula) are used. The production of binder $60 \%$ disp $1,260 \mathrm{~g} / \mathrm{cm}^{3}, p H=8,5$ viscosities 200 E2 urea formaldehyde glue is used. Dry sawdust of 50 $\mathrm{kg} / \mathrm{m}^{2}$ density is provided. Hardeners with a concentration of $20 \%$ ammonium sulfate $\left(\mathrm{NH}_{4}\right)_{2} \mathrm{SO}_{4}$ have been used and $1,05 \mathrm{~g} / \mathrm{cm}$ density is used.

MS: chip, i.e. the middle layer $4,5 \mathrm{~kg} / 1$ (1-litter).

DS: the outer surface layer of $1,5 \mathrm{~kg} / 1$ is provided.

Table 1Wood material used in experiments as samples

\begin{tabular}{|c|c|c|}
\hline Mixtures of wood & Mixtures of chemical & Density \\
\hline Pine & UF glue & $659 \mathrm{~kg} / \mathrm{m}^{3}$ \\
Beech & Wax & \\
Oak & Hardener & \\
A bit of waste wood & & \\
\hline
\end{tabular}

Full-sized boards of sheet MCP measuring $18 \times 1830$ $\times 3660 \mathrm{~mm}$ were investigated in this study because they are widely used by the Turkish panel furniture manufacturers. The general mixture properties and density of the materials used in this study are shown in Table 1 above.

\subsection{Adhesives}

The hot-melt adhesive, also known as hot glue, used in this study is a thermoplastic-based synthetic resin. Its application is recommended in locations subject to $0,8 \%$ relative humidity. Hot-melt adhesives are environmentally 
friendly glues containing no solvents. They find key applications in the manufacture of office and home furniture, particularly in the edges of various types of edge-banding materials such as wood and wood veneer, PVC, acrylic, ABS and melamine. They are solid at normal ambient temperature and need to be heated to a liquid state before bonding. They have to remain sufficiently fluid to wet-out the two surfaces during bonding. As the adhesive cools, it will revert to its solid state, completing the bond. With hot-melt adhesives, the change from solid to liquid is reversible and controlled by temperature. Wood and wood composites should be dry enough so that even if moisture is added during bonding, the moisture content of the product is at about the level expected at service assembly [14]. Adhesive failures are generally the result of using weak edge banding procedures during manufacture rather than the adhesive having an unreasonably low softening temperature [15].

\subsection{Edge banding materials}

PVC edge banding, used in this study, is manufactured with premium quality resins and highimpact modifiers that produce a product with excellent machinability, impact resistance, durability and overall appearance. Edge banding materials where the thickness is 0,$4 ; 0,8 ; 1,0$ and $2,0 \mathrm{~mm}$ and the width is $22 \mathrm{~mm}$ have been produced for this evaluation by "Ersa Mobilya ve Plastik Sanayi ve Ticaret Ltd Şti. - Plastik, Ankara". PVC edge bands were glued using hot-melt adhesives on an auto edge-banding machine. The temperature of glue application was set at $200{ }^{\circ} \mathrm{C}$ and the feed speed of the machine was $12 \mathrm{~m} / \mathrm{min}$. An edge-banding machine bonds the edge banding to the substrate, trims leading and trailing edges, trims the top and bottom flush, scraps any surplus and buffs the edge. The adhesive is applied to only one surface, using a density of $214 \mathrm{~g} / \mathrm{m}^{2}$. The type of edge bands and thicknesses are shown in Fig. 2. Number $1,2,3$ and 4 are 0,$4 ; 0,8 ; 1,0$ and $2,0 \mathrm{~mm} \mathrm{PVC}$, respectively.

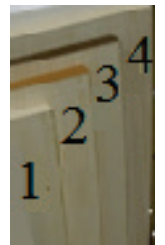

Figure 2 Edge band types

\subsection{Plan of investigations}

In this study, the bending and tensile experiments are planned based on the Taguchi design of experiments (DOE). The experimental set up is shown in Fig. 3.

DOE using the Taguchi approach is a most powerful statistical technique that can economically satisfy the needs of problem solving and optimization. By applying this technique, the effects of multiple process variables on the performance characteristics are estimated simultaneously while minimizing the number of experimental runs $[1,16]$. Minitab software was used for planning experiments and for the analysis of results based on the Taguchi method. The $L_{16}$ orthogonal array with a mixed level design was used for one factor at two levels and two factors at four levels. Tab. 2 shows the selected factors and their levels.

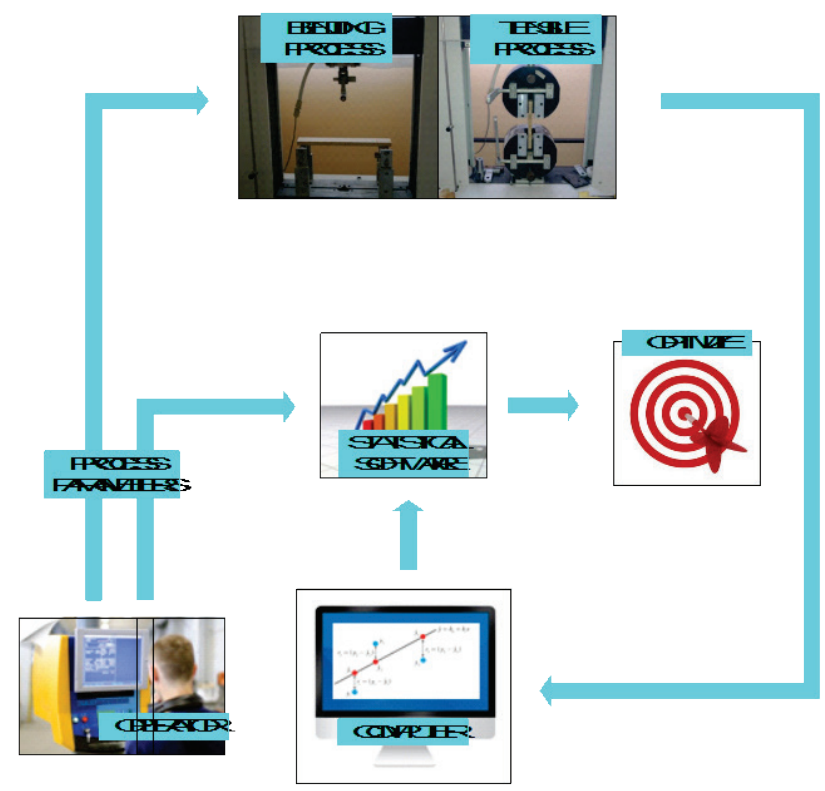

Figure3 Experimental setup for bending and tensile process

Table 2 Control factors and their levels

\begin{tabular}{|c|c|c|c|c|c|c|}
\hline Parameters & \multirow{2}{*}{ Symbol } & Unit & \multicolumn{4}{|c|}{ Levels } \\
\cline { 4 - 7 } & & 1 & 2 & 3 & 4 \\
\hline $\begin{array}{c}\text { Force } \\
\text { direction }\end{array}$ & $A$ & - & Tensile & Bending & - & - \\
\hline Edge band & $B$ & $\mathrm{~mm}$ & 0,4 & 0,8 & 1,0 & 2,0 \\
\hline $\begin{array}{c}\text { Aging } \\
\text { period }\end{array}$ & $C$ & Day & 20 & 30 & 40 & 50 \\
\hline
\end{tabular}

Using more than two levels for a factor makes it possible to study its nonlinear effects. The interactions between factors were assumed to be negligible. The factor levels were chosen in a range that is suitable for preparing the maximum number of samples in all 16 runs (each experimental setup is called a run). The total runs dictated by the Taguchi orthogonal design method are given in Tab. 3 .

Table 3 Design of experiments according to $L_{16}$ orthogonal array

\begin{tabular}{|c|c|c|c|}
\hline Run & Force direction & Edge band & Aging period \\
\hline 1 & 1 & 1 & 1 \\
\hline 2 & 1 & 1 & 2 \\
\hline 3 & 2 & 1 & 3 \\
\hline 4 & 2 & 1 & 4 \\
\hline 5 & 1 & 2 & 1 \\
\hline 6 & 1 & 2 & 2 \\
\hline 7 & 2 & 2 & 3 \\
\hline 8 & 2 & 2 & 4 \\
\hline 9 & 2 & 3 & 1 \\
\hline 10 & 2 & 3 & 2 \\
\hline 11 & 1 & 3 & 3 \\
\hline 12 & 1 & 3 & 4 \\
\hline 13 & 2 & 4 & 1 \\
\hline 14 & 2 & 4 & 2 \\
\hline 15 & 1 & 4 & 3 \\
\hline 16 & 1 & 4 & 4 \\
\hline
\end{tabular}

In order to maximize the strength of MCPin this study, signal to noise $(\mathrm{S} / \mathrm{N})$ ratio analysis was used to 
evaluate and find the optimal combination of factors. The analysis of variance (ANOVA) was performed to determine the relative significance of each factor.

\subsection{Taguchi method}

For a better understanding of this Taguchi design, the procedure of a Taguchi design is described in detail in Fig. 4. The complete procedure of the Taguchi design method can be divided into three stages, which can be described as system design, parameter design and tolerance design. Of the three design stages, the second stage -the parameter design- is the most important stage. The parameter design stage requires that the factors affecting quality characteristics in the manufacturing process have been determined [17:19]. The major goal of this stage is to identify the optimal cutting conditions that yield the biggest response value $\left(F_{\max }\right)$.

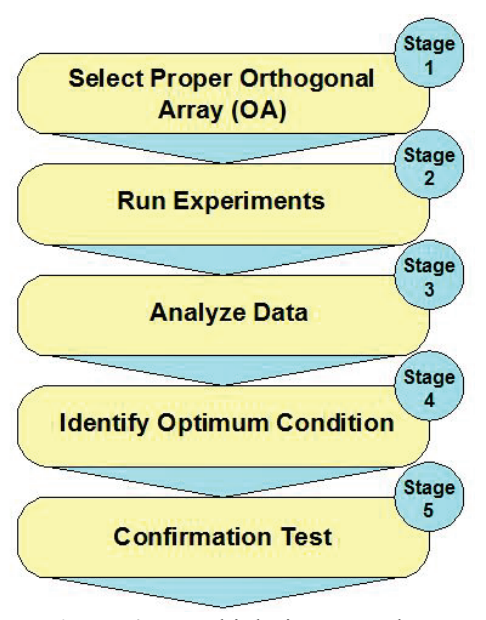

Figure 4 Taguchi design procedure

The steps included in the Taguchi parameter design are: selecting the proper orthogonal array (OA) according to the numbers of controllable factors (parameters); running experiments based on the $\mathrm{OA}$; analyzing data; identifying the optimum conditions and conducting confirmation runs with the optimal levels of all the parameters. The details regarding these steps will be described in the section on experimental design.

In the Taguchi method, the variation of the response is also examined using an appropriately chosen $S / N$ ratio. The $S / N$ ratio is the ratio of the desired signal to unwanted random noise; it represents performance characteristics for the observed data. These $S / N$ ratios, derived from the quadratic loss function, are expressed on a decibel $(\mathrm{dB})$ scale. The formula used to compute the $S / N$ ratio depends on the objective function. In the optimizing process there are three standard $S / N$ equations used to classify the objective function as: "larger the better", "smaller the better" and "nominally the best" [20,21].

\section{Experimental results and discussion 3.1 Analysis of SIN ratio}

The effect of each factor at different levels can be determined by averaging the $(S / N)$ ratios in the experiments. In this study, the optimal response conditions are analyzed by Taguchi's the "larger the better" type of performance characteristic ( $S / N$ ratio), which means the biggest response would be the ideal situation to maximize the response force $\left(F_{\max }\right)$. The $S / N$ ratio $(\mathrm{dB})$ is computed using the following equations:

$S / N=-10 \log \left[\frac{1}{n} \sum_{i=1}^{n} \frac{1}{y_{i}^{2}}\right]$,

where $i$ is the number of a trial; $y_{i}$ is the measured value of the quality characteristic for the $i^{\text {th }}$ trial experiment; $n$ is the number of repetitions for the experimental combination [22]. The corresponding $S / N$ ratio obtained from Eq. (1) for each of the sixteen experimental combinations and the experimental results $\left(F_{\max }\right)$ are illustrated in Tab. 4.

Table 4 Experimental results and $\mathrm{S} / \mathrm{N}$ ratio for response

\begin{tabular}{|c|c|c|c|c|c|}
\hline $\begin{array}{l}\text { Exp. } \\
\text { No }\end{array}$ & $\begin{array}{c}\text { Force } \\
\text { direction }\end{array}$ & $\begin{array}{l}\text { Edge } \\
\text { band }\end{array}$ & $\begin{array}{l}\text { Aging } \\
\text { period }\end{array}$ & $F_{\max }$ & $\begin{array}{l}S / N \\
(\mathrm{~dB}) \\
\end{array}$ \\
\hline 1 & Tensile & 0,4 & 20 & 726,62 & 57,23 \\
\hline 2 & Tensile & 0,4 & 30 & 724,69 & 57,20 \\
\hline 3 & Bending & 0,4 & 40 & 877,68 & 58,87 \\
\hline 4 & Bending & 0,4 & 50 & 890,91 & 59,00 \\
\hline 5 & Tensile & 0,8 & 20 & 731,25 & 57,28 \\
\hline 6 & Tensile & 0,8 & 30 & 736,32 & 57,34 \\
\hline 7 & Bending & 0,8 & 40 & 899,50 & 59,08 \\
\hline 8 & Bending & 0,8 & 50 & 908,60 & 59,17 \\
\hline 9 & Bending & 1,0 & 20 & 878,72 & 58,88 \\
\hline 10 & Bending & 1,0 & 30 & 890,26 & 58,99 \\
\hline 11 & Tensile & 0,4 & 40 & 736,79 & 57,35 \\
\hline 12 & Tensile & 0,4 & 50 & 751,70 & 57,52 \\
\hline 13 & Bending & 2,0 & 20 & 881,72 & 58,91 \\
\hline 14 & Bending & 2,0 & 30 & 897,25 & 59,06 \\
\hline 15 & Tensile & 2,0 & 40 & 763,71 & 57,66 \\
\hline 16 & Tensile & 2,0 & 50 & 772,21 & 57,75 \\
\hline
\end{tabular}

According to the explanations given above, the largest $S / N$ ratio would be the ideal situation, and the optimum cutting conditions would be determined by the level average responses from the $S / N$ ratio. Tab. 4 shows that experiment number 8 exhibits the best signal to noise ratio for the performance characteristics. Analysis of means (ANOM) is performed using the $S / N$ ratio obtained from the response; the effects of each level of each factor are presented in the $S / N$ response table (Tab. 5). In the $S / N$ response table, the rank of the parameters is significant. The rank of the parameter signifies the impact of the parameters on the response value. The level of the parameter with the highest $S / N$ ratio is the optimal level of the parameter for bending and tensile operation to simultaneously maximize the response. In addition, the delta value is the difference between the highest average for each factor and the lowest average for the same factor. From Tab. 5, it can be easily seen that the force direction had a larger impact on the response, followed by the aging period and the edge band, respectively.

The effects of all three control factors, with levels derived from Tab. 5, are individually shown by $S / N$ values in graphical form (see Fig. 5). The larger the amount of inclination the more significant the effect is; if the inclination is closer to the horizontal and the mean line, the less significant the effect is. Briefly, the optimum condition corresponding to a parameter level is shown as the peak point. 
Table $5 S / N(\mathrm{~dB})$ response table for response (Larger the better)

\begin{tabular}{|c|c|c|c|c|c|c|c|}
\hline Symbol & Parameter & Level 1 & Level 2 & Level 3 & Level 4 & Delta & Rank \\
\hline$A$ & Force direction & 57,42 & 58,99 & - & - & 1,58 & 1 \\
\hline$B$ & Edge band & 58,07 & 58,22 & 58,18 & 58,34 & 0,27 & 3 \\
\hline$C$ & Aging period & 58,07 & 58,15 & 58,24 & 58,36 & 0,29 & 2 \\
\hline
\end{tabular}

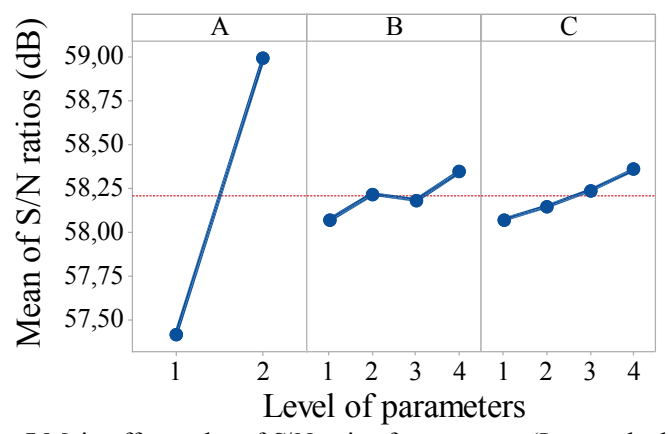

Figure 5 Main effects plot of $S / N$ ratios for response (Larger the better)

From the $S / N$ ratio analysis in Fig. 5, it can be easily seen that the force direction graph shows a larger inclination and hence is most significant,this is followed by the aging period graph. By following the criteria of the larger responses and $S / N$ ratios, the graphs in Fig. 4 were used to determine the optimal set of parameters from this experimental design. The following control factors: the force direction $(A)$ at level 2, the edge band $(B)$ at level 4 and the aging period $(C)$ at level 4 provided the best results. The resultsfor the biggest response and highest $S / N$ ratios were confirmed, and there are no conflicts in this study in determining the force direction, edge band and aging. Therefore, the optimized combination of levels for the three control factors from the analysis, was found to be $A_{2} B_{4} C_{4}$.

\subsection{Analysis of variance (ANOVA)}

Another way ofanalyzingand understanding the importance of process parameters is ANOVA. In this study, the relative significance of the parameters based on their percentage contribution has been tabulated. In order to see this effect clearly, the $P C$, which indicates the degree of influence of process parameters in the experimental response test results is calculated from Eq. (2):

$P C \%=\left(\frac{S_{i}}{S_{T}}\right) \times 100$,

where $S_{i}$ is the sum of squares for the $i^{\text {th }}$ parameter and $S_{T}$ is the total sum of squares.

The ANOVA analysis was performed for a $5 \%(P<$ $0,05)$ significance level, i.e., for a $95 \%$ confidence level of identifying the process parameters that affect the response. Statistically, the $F$-ratio provided some level of confidence in the significance levels obtained for each source of variation as shown in Tab. 6 . The $F$-ratio shows the effect of the process parameter on the response value. A higher value of $F$-ratio signifies a larger impact and hence a larger contribution to the response value. The force direction, edge band and aging influence the response values by $96,38 \%, 1,45 \%$ and $1,78 \%$, respectively. It was found that the force direction had a larger impact on the response. The other parameters only contribute slightly to the overall response. These results indicate that the force direction is significantly important for the strength of melamine-coated particle boards. The percentage influence chart for the response is shown in Fig. 6.

Table 6 Analysis of variance (ANOVA) results for $\mathrm{S} / \mathrm{N}$ ratio

\begin{tabular}{|c|c|c|c|c|c|c|}
\hline Parameter & $d o f^{a}$ & $S^{\mathrm{b}}$ & $V^{\mathrm{c}}$ & $F$-ratio ${ }^{\mathrm{d}}$ & $P C \%{ }^{\mathrm{e}}$ & $R^{2}$ \\
\hline$A$ & 1 & 9,939 & 9,939 & 1960,64 & 96,38 & \multirow{5}{*}{$99,6 \%$} \\
\hline$B$ & 3 & 0,150 & 0,050 & 9,850 & 1,45 & \\
\hline$C$ & 3 & 0,183 & 0,061 & 12,050 & 1,78 & \\
\hline Residue & 8 & 0,041 & 0,005 & & & \\
\hline Total & 15 & 10,312 & & & & \\
\hline \multicolumn{7}{|c|}{$\begin{array}{l}{ }^{\mathrm{a}} \text { Degree of freedom } \\
\mathrm{b} \text { Sum of squared deviations from the mean } \\
{ }^{\mathrm{c}} \text { Variance: mean of squares per dof } \\
{ }^{\mathrm{d}} \text { Ratio between squared deviation and the mean of square } \\
\text { residue. } \\
\text { re Relative effects of the parameters on response }\end{array}$} \\
\hline
\end{tabular}

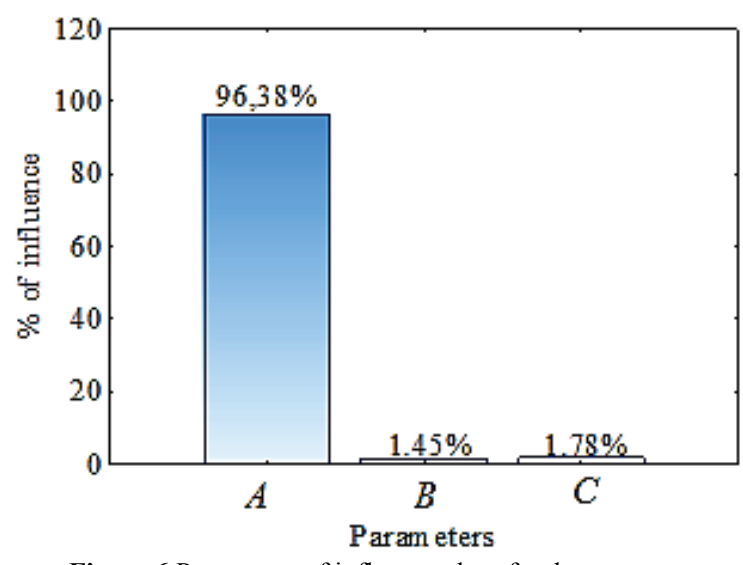

Figure 6 Percentage of influence chart for the response

\section{Confirmation run}

After the optimal levels of all of the control factors were identified, the last step in the Taguchi parameter design is conducting the confirmation run. It may be noted that if the optimal combination of parameters and their levels coincidently match with one of the experiments in the orthogonal array, then no confirmation test is required. The combination of the optimal levels of all the parameters should produce the optimal magnitude of response. This conclusion must be further supported through the confirmation runs. Estimated values of the response at optimum condition were calculated by adding the average performance to the contribution of each parameter at the optimum level using the following equation:

$$
\hat{\eta}_{o}=\eta_{o m}+\sum_{i=1}^{k}\left(\bar{\eta}_{o i}-\eta_{o m}\right)
$$


where $\hat{\eta}_{o}$ is the estimated signal to noise ratio, $\eta_{\text {om }}$ is the total mean signal to noise ratio, $\bar{\eta}_{o i}$ is the mean value of the signal to noise ratio at the optimal level and $k$ is the number of parameters affecting the multiple response [23, 24].

A confirmation test was required in this study because the optimum combination of parameters and their levels i.e. $A_{2} B_{4} C_{4}$ did not correspond to any experiment in the orthogonal array. One sample at the optimal combination of parameters and their levels $A_{2} B_{4} C_{4}$ was produced from the same material. A test specimen was prepared from this sample following the same method. After making the test specimen, the bending and tensile test were performed three times in the same way and the average response force was computed. The value of the average response force obtained from the experiment was then compared with the estimated value as shown in Tab. 7. It can be seen from this table that the experimental values of the response are very close to the estimated values. This verifies that the experimental results strongly correlate to the estimated result.

Table 7 Results of confirmation experiment

\begin{tabular}{|l|c|c|c|}
\hline \multirow{2}{*}{} & \multicolumn{2}{|c|}{ Optimal condition } & \multirow{2}{*}{ Difference, \% } \\
\cline { 2 - 3 } & Estimation & Experiment & \\
\hline Level & $A_{2} B_{4} C_{4}$ & $A_{2} B_{4} C_{4}$ & - \\
\hline Response $(\mathrm{N})$ & 897,94 & 897,25 & 0,00076 \\
\hline$S / N$ value & - & 59,06 & \\
\hline
\end{tabular}

\section{Conclusion}

This paper presents an application of Taguchi method for optimizing the process parameters in the MOR and MOE characteristics of MCP. The optimum values of process parameters were determined in order to maximize the MOR and MOE resistance $\left(F_{\max }\right)$ of MCP during the experiments. As shown in this study, the Taguchi method provides a systematic and efficient methodology for the design optimization of the process parameters, with far less effort than would be required for most optimization techniques. As described in the paper, the best result is achieved by minimizing the deviation from the target. That means the signal (product quality) to noise (uncontrollable factors) ratio should be high. It has been shown that the force direction was the most important parameter $(96,38 \%)$ that affected the response. The predicted and measured value from the confirmation test was compared by checking the variation in the percentage error. The variation percentage error was found to be $0,076 \%$. The optimum value $\left(A_{2} B_{4} C_{4}\right)$ obtained from the analysis also showed a good agreement with that of the experimental value.

\section{References}

[1] Valarmathi, T. N.; Palanikumar, K.; Sekar, S. Prediction of Parametric Influence on Thrust Force in Drilling of Wood Composite Panels. // International Journal of Mining, Metallurgy and Mechanical Engineering. 1, 1(2013), pp. $2320-4060$

[2] Thoemen, H.; Irle, M.; Sernek, M. Wood-Based Panels An Introduction for Specialists, ISBN 978-1-902316-82-6, Brunel University Press, London, 2010.
[3] Ahmad, M.; Kamke, A. Analysis of Calcutta bamboo for structural composite materials: physical and mechanical properties. // Wood Science and Technology. 39, (2005), pp. 448-459. DOI: 10.1007/s00226-005-0016-y

[4] Tankut, A. N.; Tankut, N. Evaluation of the effects of edge banding type and thickness on the strength of corner joints in case-type furniture. // Materials and Design. 31, (2010), pp. 2956-2963. DOI: 10.1016/j.matdes.2009.12.022

[5] Fathollahzadeh, Ali; Akbar Enayati, Ali; Ziya Erdil, Yusuf. Effect of laboratory-accelerated aging treatment on the ultimate strength of a 4-sided MDF kitchen cabinet. // Turk J Agric For (2013). 37, (2015), pp. 649-656.

[6] Kasal, Ali. Effects of the number of screws and screw size on moment capacity of furniture corner joints in case construction. // For Prod J. 58, (2008), pp. 36-44.

[7] Hood, J. P. Changes in oriented strand board permeability during Hot-pressing. M.Sc. Thesis, Virginia polytechnic Institute and state University, Blacksburg, 2004.

[8] Ayrilmis, N.; Jarusombuti, S.; Fueangviva, V.; Bauchongkol, P. Effects of thermal treatment of rubberwood fibres on physical and mechanical properties of medium density fibreboard. // Journal of Tropical Forest Science. 23, 1(2011), pp. 10-16.

[9] Malanit, O.; Barbu, M. C.; Fruhwald, A. The Gluability and Bonding Quality of an Asian Bamboo (Dendrocalamusasper) for The Production of Composite Lumber. // J. Tropical Forest Science. 21, 4(2009), pp.361368.

[10] Yu, Z. T.; Xu, X.; Fan, L. W.; Hu, Y. C.; Cen, K. F. Experimental Measurements of Thermal Conductivity of Wood Species in China: Effects of Density, Temperature, and Moisture Content. // Forest Products Journal. 61, 2(2011), pp. 130-135. DOI: 10.13073/0015-7473-61.2.130

[11] Bekhta, P.; Niemz, P. Effect of high temperature on the change colour, dimensional stability and mechanical properties of spruce wood. // Holzforschung. 57, 5(2003), pp. 539-546. DOI: 10.1515/HF.2003.080

[12] Stark, N. M.; Cai, Z.; Carll, C. Wood Handbook, Wood as an engineering material, Centennial Edition, Chapter 11-10 Wood-Based Composite Materials, Particle board, General Technical Report FPL-GTR-190, 2010.

[13] TS EN 312 (17.03.2005) Particleboards-Specification, Turkish Standards Institution, Ankara, Turkey.

[14] Frihart, C. R.; Hunt, C. G. Wood Handbook, Wood as an engineering material, Centennial Edition, Chapter 10-15 Adhesives with Wood Materials: Bond Formation and Performance, Bonding Process, Moisture Content Control, General Technical Report FPL-GTR-190, 2010.

[15] Tout, R. A. Review of Adhesives for Furniture. // International Journal of Adhesion and Adhesives. 20, 4(2000), pp. 269-72. DOI: 10.1016/S0143-7496(00)00002-6

[16] Poostforush, M.; Al-Mamun, M.; Fasihi, M. Investigation of Physical and Mechanical Properties of High Density Polyethylene/Wood Flour Composite Foams. // Research Journal of Engineering Sciences. 2, 1(2013), pp. 15-20.

[17] Zhang, J. Z.; Joseph, C.; Chen, E.; Kirby, D. Surface roughness optimization in an end-milling operation using the Taguchi design method. // Journal of Materials Processing Technology. 184, (2007), pp. 233-239. DOI: 10.1016/j.jmatprotec.2006.11.029

[18] Taguchi, G.; El Sayed, M.; Hsaing, C. Quality Engineering and Quality Systems. McGraw-Hill, NY, 1989.

[19] Cakir, R.; Acir, A. Optimization of cutting parameters on drill bit temperature in drilling by Taguchi method. // Measurement. 46, (2013), pp. 3525-3531. DOI: 10.1016/j.measurement.2013.06.046

[20] Cetin, M. H.; Ozcelik, B.; Kuram, E.; Demirbas, E. Evaluation of vegetable based cutting fluids with extreme pressure and cutting parameters in turning of AISI 304L by 
Taguchi method. // Journal of Cleaner Production. 19, (2011), pp. 2049-2056. DOI: 10.1016/j.jclepro.2011.07.013

[21] Gologlu, C.; Sakarya, N. The effects of cutter path strategies on surface roughness of pocket milling of 1.2738 steel based on Taguchi method. // Journal of Materials Processing Technology. 206, 1-3(2008), pp. 7-15. DOl: 10.1016/j.jmatprotec.2007.11.300

[22] Montgomery, D. C. Design and analysis of experiments. $4^{\text {th }}$ ed. New York: John Wiley, 1997.

[23] Taguchi, G. Introduction to Quality Engineering. Asian Productivity Organization, Tokyo, 1990.

[24] Pandey, R. K.; Panda, S. S. Multi-performance optimization of bone drilling using Taguchi method based on membership function. // Measurement. 59, (2015), pp. 9-13. DOI: 10.1016/j.measurement.2014.09.038

\section{Authors' addresses}

Assit. Prof. Cevdet Sacli, Ph.D.

Selcuk University,

Technical Science Collage,

Program of Furniture and Decoration,

42075, Konya, Turkey

E-mail: csacli@selcuk.edu.tr

Assoc. Prof. Suleyman Neseli, Ph.D.

Selcuk University,

Faculty of Technology,

Department of Mechanical Engineering,

42075, Konya, Turkey

E-mail: sneseli@selcuk.edu.tr 